\title{
CONSTITUENT POWER AND THE RIGHT TO RESIST OR WHAT HAPPENED TO THE UKRAINIAN CONSTITUTION IN 2014?
}

\section{Boryslavska $\mathbf{O}$.}

\section{INTRODUCTION. WHAT HAPPENED? SHORT HISTORY}

Today, several years later, the events that took place in Ukraine in 2013-2014 still remain significant for the political, legal and, most importantly, constitutional development of Ukraine. At the same time, they are still at the centre of legal and philosophical discussions. These discussions centred on what happened to the Ukrainian Constitution in 2014 from the legal rather than the political point of view. Was it the way of exercising constituent power or perhaps a kind of the arbitrariness of the Parliament? Was it a political step or a juridical one as well? Was it the way of the right to resist exercising and, then, what is their interrelation?

Many unanswered questions make us return to the above events over and over again. Maybe one of the reasons why they have not yet been resolved is that the Constitutional Court of Ukraine abstained from this despite having at least several possibilities for doing this when adjudicating and enacting judgments in several cases. Some cases are still pending before the Constitutional Court, including the one on the constitutional submission of the former President of Ukraine ${ }^{1}$, who directly challenged the 2014 Law on the deprivation of V. Yanukovych the title of President of Ukraine $^{2}$. It is important to understand that the law was adopted in conjunction with other landmark acts of the Revolution of Dignity: Law on the Reinstatement of Certain Provisions of the Ukrainian Constitution of February 21, 2014 ${ }^{3}$, Verkhovna Rada resolution on the text of the

\footnotetext{
${ }^{1}$ Konstytutsiine podannia Prezydenta Ukrainy shchodo vidpovidnosti Konstytutsii Ukrainy (konstytutsiinosti) Zakonu Ukrainy „Pro pozbavlennia V. Ianukovycha zvannia Prezydenta Ukrainy“ vid 4 liutoho 2015 roku № 144-VIII. URL: http://www.ccu.gov.ua/novyna/ konstytuciyni-podannya-za-stanom-na-29-chervnya-2016-roku (in Ukrainian).

2 Zakon Ukrainy "Pro pozbavlennia V. Yanukovycha zvannia Prezydenta Ukrainy" vid 4 liutoho 2015 roku № 144-VIII. URL: https://zakon.rada.gov.ua/laws/show/144-19 (in Ukrainian).

${ }^{3}$ Zakon Ukrainy "Pro vidnovlennia dii okremykh polozhen Konstytutsii Ukrainy" vid 21.02.2014 №742-VII. URL: https://zakon.rada.gov.ua/laws/show/742-18 (in Ukrainian).
} 
Constitution of Ukraine (in connection with the renewal of its provisions) ${ }^{4}$ and Verkhovna Rada Resolution On Responding to the Facts of Violation of an Oath by the Judge of the Constitutional Court ${ }^{5}$.

A full understanding of the problem under consideration requires a brief description of the modern constitutional history of Ukraine. The constitutional process after the proclamation of the state sovereignty of Ukraine was quite lengthy and complex. This was largely due to a certain struggle between the ideologies of socialist-Soviet and liberal-democratic. The difficulties were exacerbated by the composition of the Verkhovna Rada of that (second) convocation, which was mainly staffed by the representatives of the former Communist Party who were the bearers of the respective ideology 6 .

After years of debate and various political events, the Constitution of Ukraine was adopted by the Parliament on June 28, 1996. Despite its shortcomings, it was consistently operating for eight years. The first amendments to the Constitution were made in December 8, 2004 as a result of the events that became known as the "Orange Revolution", when the society did not recognize the officially announced results of the presidential elections. Therefore, the two laws amending the Constitution and holding the third round of the presidential elections between the two candidates who received the most electoral votes in the first round were simultaneously adopted by the so-called "package" voting. It should be noted that the adoption of the Law on Amendments to the Constitution was a gross violation of the procedures analysed in detail in the opinion of the Venice Commission ${ }^{7}$. This became the formal basis for the abolition of the constitutional reform in 2010.

Nevertheless, the submission to the Constitutional Court had been brought in before, but in 2008 the Court refused to hear the case, referring

${ }^{4}$ Postanova Verkhovnoi Rady Ukrainy "Pro tekst Konstytutsii Ukrainy v redaktsii 28 chervnia 1996 roku, iz zminamy i dopovnenniamy, vnesenymy zakonamy Ukrainy vid 8 hrudnia 2004 roku № 2222-IV..." vid 22.02.2014. URL: https://zakon.rada.gov.ua/ laws/show/750-18 (in Ukrainian).

5 Postanova Verkhovnoi Rady Ukrainy "Pro reahuvannia na fakty porushennia suddiamy Konstytutsiinoho Sudu Ukrainy prysiahy suddi" vid 24.02.2014. URL: https://zakon.rada.gov.ua/laws/show/775-18 (in Ukrainian).

6 People's Deputies of Ukraine of the 2nd convocation (1994-1998). Data from the official site of the Verkhovna Rada of Ukraine. URL: http://w1.c1.rada.gov.ua/pls/ radan_gs09/d_index_arh?skl=2 (in Ukrainian).

Venice Commission Opinion on the amendments to the Constitution of Ukraine adopted on 8.12.2004, adopted by the Commission at its 63rd plenary session, Venice, 10-11 June 2005. URL: https://www.venice.coe.int/webforms/documents/?pdf= CDL-AD(2005)015-e. 
to the fact that the Law on Amendments to the Constitution after its entry into force becomes the integral part of the Constitution, and the Court does not have the authority to revise the Constitution. After the presidential elections in 2010, the Constitutional Court changed its legal position and took into preceding the Law on Amendments to the Constitution in 2004. It found it unconstitutional due to the violations of the aforementioned procedures and reinstated the Constitution of 1996. This step of the Constitutional Court was criticized as political rather than clear juridical inland, as well as by the Venice Commission.

Due to the events of late 2013 - early 2014, the Verkhovna Rada of Ukraine again recognized the Constitution as amended in 2004 in force, referring to the fact that the Constitution is an act of constituent power, and amending the Constitution is within the competence of the parliament (Section XIII of the Constitution), so the Constitutional Court which carried its decision in 2010 went beyond its powers. This was not done by adopting a constitutional law, as required by the section XIII of the Constitution, but by means of an ordinary law by simple majority of deputies. This law that is the subject of much debate is the focus of this research.

\section{Two approaches to interpreting the restoration of the 2014 Constitution}

The problem of restoring the 2004 Constitution of Ukraine in 2014, its legality as well as legitimacy of the Basic Law at a whole is viewed from different angles, in particular from the standpoint of the right to resist, post-revolutionary legitimation, and political expediency, etc. In our opinion, from a constitutional point of view, the answer to this difficult question lies in the correlation between two principles that are important in the doctrine and practice of constitutionalism - the rule of law and the supremacy of the constitution. They, in turn, are treated differently, depending on the principles of legal thinking: positivistic or naturalistic. That is why these principles are the basis for two significant approaches to interpreting the events related to the restoration of the 2014 Constitution as well as their consequences.

Along with the existence of a number of theories of law - positivist, metaphysical, sociological, psychological and others - it is generally acknowledged that the main directions in the understanding of law are naturalism and jus-positivism, and they "set the tone" in understanding the nature and essence of constitutional and legal phenomena.

Naturalistic type of reasoning is based on the idea of the existence of higher, permanent, state-independent norms and principles that embody 
reason, justice and which, regardless of their origin (God, human nature, nature, etc.), limit the state in its activities and the creation of positive law. As G. Ellinek points out, from the first moment when they began to think about the nature of law at all, there was a belief in the existence of natural law, the true power of which does not follow from any human establishment, but which, on the contrary, is the highest norm for the assessment of existing law ${ }^{8}$. It was the idea of state restriction that formed the basis for the formation of constitutionalism, which testifies to its affinity with naturalism. The emergence of constitutionalism as a doctrine and its implementation in the form of relevant political and legal practice occurred in the era of struggle against absolutism, when philosophers and political figures appealed to natural human rights as the natural boundaries of the monarch's power. Thus, the notion of state power restriction by natural law, primarily human rights, is fundamental in the content of constitutionalism.

Regardless of the various directions within the framework of the naturalistic approach, its essence in understanding constitutional phenomena is that the constitution is not valuable in itself, but as an effective means of restricting state power, guaranteeing individual freedom, freedom of civil society, limiting state arbitrariness, and preventing tyranny.

Naturalism draws attention not so much to the letter of law and constitution as to their spirit: nature, principles, and purpose. Another situation is related to positivism, which emphasizes formal aspects: written norms and procedures. That is why a change of emphasis on understanding the essence of constitutionalism from meaningful to formal occurred during the period of domination in the social sciences, including the jurisprudence of positivism (late 19th - early 20th centuries). Constitutionalism gradually evolved from the doctrine of the ways and forms of restricting state power in order to ensure individual freedom of the doctrine of the constitution and the order of exercising state power established by it.

Legal positivism is usually associated with great scepticism about the ability to find rational and valid criteria of fairness in a system of values and social rules. The most common assumption is that values and rules of conduct are quite controversial, while there are no objective principles that can be appealed in the event of such a contradiction.

${ }^{8}$ Ellynek H. (1905) Deklaratsiia pravъ cheloveka y hrazhdanyna per. s nem. pod red. Vormsa A.Э. Moskva. 


\section{Positivistic approach. rule of law as a rule of the law}

In its classic form, positivism views law as a product of state will, the activity of the state, reflected in normative acts. It requires strict adherence to the law or prescription, especially to the letter rather than the spirit of Constitution. Based on Kelsen's theory of pure law, the positivist approach in constitutionalism does not focus on the content of ideas, but on the hierarchy of norms.

Kelsen considerers the constitution as a higher standard, which is established and amended by a special procedure, but does not distinguish its nature from ordinary law:

"A written constitution has the character of an objectively binding rule if laws and regulations adopted thereunder are regarded as binding legal rules",

Under the influence of his opinions for a long period of time constitutional phenomena and processes were viewed from the perspective of formal approaches. Therefore, formal conformity with the Constitution was recognized as a greater achievement than compliance with the ideas of law and justice. But the experience of fascist-nazi systems in Germany and Italy in the early 20th century, which were based on the positivist interpretation of the law and functioned generally in accordance with the laws they produced, on the one hand, contributed to the revival of the idea of natural law and, on the other, stimulated researchers to seek more robust safeguards and new paradigms in law.

The interpretation of the events we consider from the perspective of a positivist approach aims at analyzing compliance with formal law when restoring the 2004 Constitution. At first glance, this approach is fully justified, since it emphasizes compliance with the procedure established by the Constitution for its amendment. However, it does not answer the whole set of questions that arise in a complex, structured society that is either liberal-democratic or merely trying to become one.

\section{Jus-naturalistic approach}

In its classical sense, proposed by the English constitutionalist Albert Dicey, the rule of law has three components. First, it denies the arbitrariness of the authorities, arbitrary or discretionary powers to enforce coercion by prohibiting punishment or prosecution of a person, unless he or she commits a violation of the law and solely on the basis of a court

${ }^{9}$ Kelzen Hans (2004) Chyste pravoznavstvo: z dod. Problemy Spravedlyvosti. Pereklad z nim. O. Mokrovolskoho. Kyiv, Yunivers. 
judgment. Secondly, the rule of law provides for the equality of all, the absence of any privileges or immunities of public officials; for actions taken in the course of their official duties, they shall be held liable in the ordinary procedure in ordinary courts. Third, the rule of law is the result of the totality of "court decisions that determine the rights of individuals in individual cases that have been proceeded by courts" ${ }^{10}$.

In the modern sense, the rule of law in the English version provides for the restriction of state power in favour of individual freedom and human rights, and is based on the powerful interpretative and law-making powers of the courts that establish such lawful restrictions. In the absence of a written constitution, however, the rule of law works here. To a large extent, as B. Tamanaha says, it works because of the "widespread and indisputable conviction of the rule of law, the inviolability of certain fundamental restrictions imposed to the state power, and not through the functioning of specific legal mechanisms" ${ }^{\prime 1}$.

The idea of "rule of law, not a man" was transferred from England to America, where it was embodied in the doctrine of "formal legality". Therefore, the American model of constitutionalism can be briefly characterized by the concept of "the rule and stability of a written constitution to guarantee individual freedom". It was in the United States for the first time that the supremacy of the Constitution as a fundamental law was introduced. However, it became apparent later that the understanding of the rule of law in its purely formal sense - as the rule of written law - was quite dangerous. As Joseph Ratz noted,

"A non-democratic legal system, based on the denial of human rights, on extensive poverty, on racial segregation, sexual inequalities, and religious persecution may, in principle, conform to the requirements of the rule of law better than any of the legal systems of the more enlightened Western democracies. This does not mean that it will be better than those Western democracies. It will be an immeasurably worse legal system, but it will excel in one respect: in its conformity to the rule of law ${ }^{12}$.

The modern doctrine of American constitutionalism is inherent in the principles of the supremacy of the constitution and the rule of law in its material sense. It means that:

${ }^{10}$ Dicey A. V. Introduction to the Study of the Law of the Constitution. Indianapolis: Liberty Classics, 1982. P. 102-114.

${ }^{11}$ Braian Tamanaha. Verkhovenstvo prava. Istoriia. Polityka. Teoriia. Kyiv, Vydavnychyi dim "Kyievo-Mohylianska akademiia”, 2007. S.68-69. (in Ukrainian).

12 Josef Raz. The Rule of Law and its Virtue. Oxford, Clarendon Press; New York, Oxford University Press, 1979. P. 212-214. 
"Rule of law, then, is not rule of the law, but a doctrine concerning what the law ought to be - a set of standards, in other words, to which the laws should conform. Merely because a tyrant refers to his commands and arbitrary rulings as "laws" does not make them so. The test is not what the rule is called, but whether the rule is general, known, and certain; and also whether it is prospective (applying to future conduct) and is applied equally. These are the essential attributes of good laws-laws that restrain but do not coerce, and give each individual sufficient room to be a thinking and valuing person, and to carry out his own plans and designs" ${ }^{\text {. }}$.

The constitution itself is then interpreted on the basis of the ideas of law (not the law) and through their prism. The material sense of the rule of law is also common in Europe, especially after the Second World War.

The European model of constitutionalism is characterized by the existence of a written constitution endowed with such qualities as its supremacy and stability, as well as the rule of law represented by two traditions: the rule of law and the legal state (Rechtsstaat in Germany). Based on the legal traditions established here, the supremacy of the constitution is interpreted taking into account its nature, and especially when solving constitutional and legal problems that arise in practice. It is important here to clarify not only the formal features of the supremacy of the constitution, the procedure for its amendment, which, no doubt, are extremely important, but also the nature of the primacy of this act. After all, the constitution is superior not a priori, but as the result of its constituent nature.

The doctrine of the constituent power states that it is the constituent power of the people that is the supreme manifestation of sovereignty and primary authority over all other powers (legislative, executive and judicial). That is why public authorities are bound by the constitution which has supremacy over other laws and legislation by virtue of its constituent nature. This nature also explains such a feature of the constitution as its high stability: since it is an act of the constituent power, the procedure for amending it is much more complicated than the ordinary legislative process and sometimes requires the direct will of the people as the subject of primary power.

Thus, the purpose of adopting a constitution is to exercise the power of the people, as well as to establish constitutional limits over the activity of the state, its bodies and officials. Going beyond these boundaries will

13 James McClellan. (2000) Liberty, Order, and Justice: An Introduction to the Constitutional Principles of American Government. (3rd ed.) Indianapolis: Liberty Fund. P. 350. 
inevitably lead to an encroachment on the sphere of individual freedom, fundamental human rights and will be interpreted as state arbitrariness. Therefore, the supremacy of the constitution is intended to guarantee and ensure the principles of the relationships between human, people (society) and the state, which are established in the constitution.

With regard to the rule of law in its continental European sense, there are two traditions that are reflected in the formal (limited by the law) and material (limited by law) interpretations of this principle. An attempt to generalize and unify them was made by the Council of Europe Venice Commission. Its Rule of Law Report states that the rule of law is a fundamental value encompassing the totality of formal and substantive features that provide for the consensus on the rule of law, as well as those of the Rechtsstaat which are not only formal but also substantial or material (materieller Rechtsstaatsbegriff). These are:

1. "Legality, including a transparent, accountable and democratic process for enacting law;

2. Legal certainty;

3. Prohibition of arbitrariness;

4. Access to justice before independent and impartial courts, including judicial review of administrative acts;

5. Respect for human rights;

6. Non-discrimination and equality before the law"14.

Thus, human rights and the prohibition of arbitrariness are important components of the rule of law, along with legality and other formal and substantive components. And when such arbitrariness becomes a reality under the current constitution, it shows not only the violation of the socalled social contract by the state, the principles of the relationship between human, society and the state, which were reflected in it, but also the rule of law. At the same time, the supremacy of the constitution, combined with its stability, seems to preserve this state.

Thus, the supremacy of the constitution is its feature, which aims to give the constitutional norms and principles a fundamental and stable character in comparison with other legal acts and norms. In the context of a constitutional state - a state that is truly restricted by human rights and freedoms by constitutional means - the rule of law contributes to

${ }^{14}$ Venice Commission Report on the Rule of Law Adopted by the Venice Commission at its 86th plenary session (Venice, 25-26 March 2011), CDL-AD(2011)003rev (article 41) // [Електронний pecypc] Режим доступу: http://www.venice.coe.int/webforms/documents/ ?pdf=CDL-AD(2011)003rev-e. 
the stability of such a constitutional system, and through the exercise of a restrictive function against the state, also to the rule of law. At the same time, in cases of significant deviation from the constitutional principles of government, usurpation of power or state arbitrariness, the constitution does not carry out this mission; the legislation and the order created on its basis are contrary to the law, and therefore people can exercise their natural right to resist.

\section{The right to resist}

The right to resist oppression (the right to rebellion) is an integral part of the doctrine of constitutionalism that accompanies it throughout the history of existence. Political theory explores the right to resist, starting with the first mention of its existence in ancient times. The peculiar interpretations of this right are inherent in different societies of the Middle Ages. In the Age of Enlightenment, when this right first appeared in political and legal documents, its importance grew. However, the universal recognition of the right of resistance by the international community came in the twentieth century, which was reflected in its inclusion into international legal acts. Thus, the preamble to the 1948 Universal Declaration of Human Rights mentions the possibility, «as a last resort, to rebellion against tyranny and oppression”, when human rights are not protected by the rule of law ${ }^{15}$.

In the modern interpretation, the people's right to resistance is seen as a natural law (a component of the rule of law), a constitutional right (enshrined in a number of constitutions of modern states), and the right of the people, reflected in international legal acts ${ }^{16}$. Its origin is related to the natural right of a person to protect himself from violence by any means. The most striking natural character of the right to resist (rebellion) is revealed in the US Declaration of Independence of $1776^{17}$ (the right to rebellion derives from natural rights, and in the case of unlimited despotism, it is also the duty of the people), as well as in Article 33 of the 1789 French Declaration of the Rights of $\operatorname{Man}^{18}$.

${ }^{15}$ Universal Declaration of Human Rights, 1948. URL: https://www.ohchr.org/ EN/UDHR/Documents/UDHR_Translations/eng.pdf.

${ }^{16}$ Pohrebniak S.P., Uvarova E.A. (2013) Soprotyvlenye uhnetenyiu. Vosstanye. Revoliutsyia (teoretyko-pravovoy̆ analyz $\mathrm{v}$ svete doktrynd prav cheloveka). Pravo $i$ hromadianske suspilstvo. №2. S. 4-61.

17 The Declaration of Independence, 1776. URL: https://history.state.gov/milestones/ 1776-1783/declaration.

18 Declaration of the Rights of Man. Approved by the National Assembly of France, August 26, 1789. URL: https://avalon.law.yale.edu/18th_century/rightsof.asp. 
According to the doctrine of constitutionalism, public authorities must be bound by certain restrictions designed to guarantee their legitimate activity in accordance with constitutional principles and respect for human rights. But if the restrictions stipulated by the constitution do not work, the extreme measure remains - the people as the sovereign and the source of power can resort to resistance and rebellion, in order to restore the constitutional order. Such actions must be proportionate; in fact, according to the German law philosopher Arthur Kaufman, this resistance (rebellion) is different from the revolution, which always seeks to completely replace the constitutional order with a new one ${ }^{19}$.

The right to resist is the last resort, and therefore it is considered legitimate only in exceptional cases. The reasons for its implementation are situations of so-called "significant legal alienation", with the law or practice of its application is radically and systematically different from the will of the majority of the society ${ }^{20}$. It is necessary to distinguish the right to resistance from various state coups, in which active actions (actually resistance) are committed by persons who themselves are part of the state mechanism $^{21}$.

The criteria of lawfulness and permissibility of the right to resist are derived from its features, which were distinguished by the professors of the University of Chicago in their study based on the analysis of empirical material. These characteristics were attributed to the following:

First, the purpose of exercising the right to resist is to restructure the existing regime or restore the constitutional order; secondly, a high (unacceptable) threshold of abuse of power, which makes it impossible to use of other legitimate means of struggle is a prerequisite for the exercise of the right to resist; thirdly, when exercising the right to resist, an alternative program of social development must be formulated (this is what makes it different from protests) $)^{22}$.

${ }^{19}$ Arthur Kaufmann. (1985-1986) Small Scale Right to Resist. New English Law Reviw. P. 571-574.

${ }^{20}$ Tom Ginsburg, Daniel Lansberg-Rodriguez, Mila Versteeg (2012) When to Overthrow Your Government: the Right to Resist in the World's Constitutions. The Law School the University of Chicago, Public Law and Legal Theory Working Paper no. 406, November 2012. P. 1191-1192.

${ }^{21}$ Pohrebniak S.P., Uvarova E.A. (2013) Soprotyvlenye uhnetenyiu. Vosstanye. Revoliutsyia (teoretyko-pravovoy̆ analyz v svete doktrynы prav cheloveka). Pravo $i$ hromadianske suspilstvo. №2. S. 4-61.

${ }^{22}$ Tom Ginsburg, Daniel Lansberg-Rodriguez, Mila Versteeg (2012) When to Overthrow Your Government: the Right to Resist in the World's Constitutions. The Law School the University of Chicago, Public Law and Legal Theory Working Paper no. 406, November 2012. P. 1191-1195. 
So, let us now analyse the events that preceded the adoption on February 21, 2014 of the Law on the renewal of certain provisions of the Constitution of Ukraine on the basis of the aforementioned grounds and signs of the people's right to resist.

From 2010, former President V. Yanukovich pursued his policy that demonstrated the course towards concentration of power. One on the first and most important steps towards this was the formation of a parliamentary coalition around the Party of Regions (presidential party). According to the legislation (valid at that time) and its interpretation by the Constitutional Court, only the parliamentary fraction was the subject of coalition formation. But the Constitutional Court of Ukraine changed its previous opinion (as it was suspected, under pressure from the head of the state) and recognised the right of individual deputies to join the coalition. It was the way of creating the pro-presidential coalition in the parliament which opened up opportunities for the excessive concentration of powers by the President.

The continuation of this path was the formal renewal of the broad constitutional powers of the President. Legally this was done in 2010 by the decision of the Constitutional Court of Ukraine that declared the 2004 Law on Amendments to the Constitution of Ukraine unconstitutional (it was described at the beginning of this study). Although the Constitutional Court had formal grounds for enacting such a judgement, as the 2004 Law was adopted with gross violation of the procedure, it was obvious that the judgment was aimed at giving the excessively wide authority to the President. Presidential power became less restricted, and cases of abuse became apparent. Added to this was the increasing arbitrariness of investigators and law enforcement agencies, and society was clearly aware of the injustice and inability of the state to protect everyone from it.

The latest manifestation of the presidential arbitrariness was the refusal of the head of state to sign the Association Agreement with the EU with a legally fixed foreign policy on European integration ${ }^{23}$. This caused a peaceful protest of Ukrainian citizens, which, however, could not yet be regarded as resistance or rebellion. However, further events, including law enforcement actions against peaceful protesters (with a clear violation of not only the principles of law, human dignity, but also the rules of current legislation), as well as the adoption on January 16, 2014, of a package of anti-legal laws, which significantly restricted constitutional human and

23 Zakon Ukrainy "Pro zasady vnutrishnoi i zovnishnoi polityky" vid 08.07.2018 r. URL: https://zakon.rada.gov.ua/laws/show/2411-17 (in Ukrainian). 
citizen rights, were the signs of "significant legal alienation" that arose from the formation of a system of government with an excessive concentration of power in the hands of the President. All this testifies to the achievement of the "high threshold of abuse" of power, which is unacceptable, and therefore, is a prerequisite for people to exercise their right to resist.

The goal of the protesters was not only the resignation of the president and the government, but also the formation of a new system of public authority, which was supposed to be protected from usurpation and free from corruption. Such somewhat idealized goals, however, were formulated in the form of several claims to power, including the restoration of the constitutional order envisaged by the 2004 Constitution of Ukraine. Finally, the protesters proposed an "alternative program of social development”, which consisted of building a democratic state with human and civil rights and freedoms, returning to a European integration course with the introduction of European standards of social and state development.

Thus, the abovementioned gives the reason to qualify the events of November 21, 2013 - February 2014 (Revolution of Dignity), taking into account their causes, prerequisites, content and orientation as the realization by the Ukrainian people of the right to resist arbitrary power.

\section{CONCLUSIONS}

In the science of constitutional law, the supremacy of the Constitution is usually regarded as an element of the rule of law. According to S. Golovatyi, the principle of the hierarchy of legal norms, the content of which is that the Constitution is endowed with the highest legal force, is an element of the integral principle of the rule of $\operatorname{law}^{24}$. Professor M. Kozyubra believes that it would be wrong to oppose the rule of law and the supremacy of the constitution. In his view, the supremacy of the constitution is one of the decisive components of the rule of law ${ }^{25}$.

We agree that in the context of evolutionary constitutional development, with embodied in the constitutional text principles (or at least the majority of them) being put into practice, whereby the actual constitutional order corresponds to its main parameters declared in the

24 Holovatyi S. (2011) Triada yevropeiskykh tsinnostei - verkhovenstva prava, demokratiia, prava liudyny - yak osnova ukrainskoho konstytutsiinoho ladu. Pravo Ukrainy. № 5. S. 159-174.

${ }^{25}$ Koziubra M.I. (2012) Verkhovenstvo prava i Ukraina // Pravo Ukrainy. № 1-2. C. 30-63. 
Constitution, the supremacy of the Basic Law rule facilitates the implementation of the rule of law and is its element. At the same time, practice shows that sometimes in the implementation of the Constitution the ideas embodied in it are deformed, leading to the opposite effect: authoritarian regime comes to power instead of democracy, while state arbitrariness occurs instead of a constitutional state with protected human rights and freedoms, etc. We believe that in such situations, the supremacy of the Constitution protects neither the primary ideas of law, nor incorporated in it the principles of the relationship between man, society and the state, but the regime that actually emerged as a result of mutations in its implementation. In such cases, we seem to choose between the supremacy of the Constitution and the rule of law.

This is the situation, in our view, that occurred as a result of the Revolution of Dignity 2013-2014. The neglect of the constitutional prescriptions by certain state-government institutions, which became systemic and comprehensive, the concentration of excessive powers by the President testified to a gross violation of the principles of constitutionalism; at the same time the supremacy of the constitution, combined with its stability, "preserved" such a regime, preventing evolutionary development of Ukraine as a constitutional state. This raises the question of priority between the supremacy of the Constitution and its norms regarding the procedure for amending the Constitution or the rule of law and implementing the results of the right of the people to resist arbitrary power. This example demonstrates that in such extraordinary cases, in situations of non-evolutionary constitutional development, the principles of supremacy of the Constitution and the rule of law may not coexist peacefully.

In our view, the constitution and its procedures are only one element of the constitutional system of the government, the purpose of which is to guarantee human rights and freedoms, including the right to a just and democratic government. However, if the state government ignores the constitutional restrictions that lead to a justified exercise of the people's right to resist arbitrary power, then the rule of law should have priority in such cases. Thus, the 2014 renewal of the 2004 Constitution of Ukraine may be regarded as an effect of the rule of law (contrary to the supremacy of the constitution), which, based on the doctrine of constitutionalism, is possible as a result of the struggle against usurpation, resistance of a political nation to arbitrary power, and can be applied to the restoration of the constitutional system of government based on the will of the people. 


\section{SUMMARY}

Today, several years later, the events of the Revolution of Dignity that took place in Ukraine in 2013-2014, still remain significant for the political, legal and constitutional development of Ukraine, and are at the centre of discussions. They centred on the issues of what happened to the Ukrainian Constitution in 2014 from the legal rather than the political point of view. Was it the way of exercising constituent power or perhaps a kind of the arbitrariness of the Parliament? Was it a political step or a juridical one as well? Was it the way of the right to resist exercising and, then, what is their interrelation?

This study is an attempt to review them through the interrelation and correlation between the principles of rule of law and supremacy of the constitution, as well as the constituent power and the right to resist. It is concluded that the constitution (with the constituent power as its nature and supremacy of the constitution as the result) is only one element of the constitutional system of the government, the purpose of which is to guarantee human rights and freedoms, including the right to a just and democratic government. However, if the state government ignores the constitutional restrictions that lead to a justified exercise of the people's right to resist arbitrary power, then the rule of law should have priority in such cases.

\section{REFERENCES}

1. Konstytutsiine podannia Prezydenta Ukrainy shchodo vidpovidnosti Konstytutsii Ukrainy (konstytutsiinosti) Zakonu Ukrainy „Pro pozbavlennia V.Ianukovycha zvannia Prezydenta Ukrainy“ vid 4 liutoho 2015 roku № 144-VIII. URL: http://www.ccu.gov.ua/novyna/ konstytuciyni-podannya-za-stanom-na-29-chervnya-2016-roku Ukrainian).

2. Zakon Ukrainy "Pro pozbavlennia V. Yanukovycha zvannia Prezydenta Ukrainy” vid 4 liutoho 2015 roku № 144-VIII. URL: https://zakon.rada.gov.ua/laws/show/144-19 (in Ukrainian).

3. Zakon Ukrainy "Pro vidnovlennia dii okremykh polozhen Konstytutsii Ukrainy" vid 21.02.2014 № 742-VII. URL: https://zakon.rada.gov.ua/laws/show/742-18 (in Ukrainian).

4. Postanova Verkhovnoi Rady Ukrainy "Pro tekst Konstytutsii Ukrainy v redaktsii 28 chervnia 1996 roku, iz zminamy i dopovnenniamy, vnesenymy zakonamy Ukrainy vid 8 hrudnia 2004 roku № 2222-IV..." vid 22.02.2014. URL: https://zakon.rada.gov.ua/laws/show/750-18 (in Ukrainian). 
5. Postanova Verkhovnoi Rady Ukrainy "Pro reahuvannia na fakty porushennia suddiamy Konstytutsiinoho Sudu Ukrainy prysiahy suddi" vi 24.02.2014. URL: https://zakon.rada.gov.ua/laws/show/775-18 (in Ukrainian).

6. People's Deputies of Ukraine of the 2nd convocation (1994-1998). Data from the official site of the Verkhovna Rada of Ukraine. URL: http://w1.c1.rada.gov.ua/pls/radan_gs09/d_index_arh?skl=2 (in Ukrainian).

7. Venice Commission Opinion on the amendments to the Constitution of Ukraine adopted on 8.12.2004, adopted by the Commission at its 63rd plenary session, Venice, 10-11 June 2005. URL: https://www.venice.coe.int/webforms/documents/?pdf=CDL$\mathrm{AD}(2005) 015$-e.

8. Ellynek H. (1905) Deklaratsiia pravъ cheloveka y hrazhdanyna per. s nem. pod red. Vormsa A.Э. Moskva.

9. Kelzen Hans (2004) Chyste pravoznavstvo: z dod. Problemy Spravedlyvosti. Pereklad z nim. O. Mokrovolskoho. Kyiv, Yunivers.

10. Dicey A. V. (1982) Introduction to the Study of the Law of the Constitution. Indianapolis: Liberty Classics.

11. Braian Tamanaha (2007) Verkhovenstvo prava. Istoriia. Polityka. Teoriia. Kyiv, Vydavnychyi dim "Kyievo-Mohylianska akademiia". S. 68-69. (in Ukrainian).

12. Josef Raz (1979). The Rule of Law and its Virtue. Oxford, Clarendon Press; New York, Oxford University Press.

13. James McClellan. (2000) Liberty, Order, and Justice: An Introduction to the Constitutional Principles of American Government. (3rd ed.) Indianapolis: Liberty Fund.

14. Venice Commission Report on the Rule of Law Adopted by the Venice Commission at its 86th plenary session (Venice, 25-26 March 2011), CDL-AD(2011)003rev (article 41) // [Електронний ресурс] Режим доступу: http://www.venice.coe.int/webforms/documents/ ?pdf=CDL-AD(2011)003rev-e.

15. Universal Declaration of Human Rights, 1948. URL: https://www.ohchr.org/EN/UDHR/Documents/UDHR_Translations/ eng.pdf.

16. Pohrebniak S.P., Uvarova E.A. (2013) Soprotyvlenye uhnetenyiu. Vosstanye. Revoliutsyia (teoretyko-pravovoy̆ analyz v svete doktrynы prav cheloveka). Pravo i hromadianske suspilstvo. № 2. S. 4-61.

17. The Declaration of Independence, 1776. URL: https://history.state.gov/milestones/1776-1783/declaration. 
18. Declaration of the Rights of Man. Approved by the National Assembly of France, August 26, 1789. URL: https://avalon.law.yale.edu/ 18th_century/rightsof.asp.

19. Arthur Kaufmann. (1985-1986) Small Scale Right to Resist. New English Law Reviw. P. 571-574.

20. Tom Ginsburg, Daniel Lansberg-Rodriguez, Mila Versteeg (2012) When to Overthrow Your Government: the Right to Resist in the World's Constitutions. The Law School of the University of Chicago, Public Law and Legal Theory Working Paper no. 406, November 2012.

21.Zakon Ukrainy "Pro zasady vnutrishnoi i zovnishnoi polityky" vid 08.07.2018 r. URL: https://zakon.rada.gov.ua/laws/show/2411-17 (in Ukrainian).

22. Holovatyi S. (2011) Triada yevropeiskykh tsinnostei verkhovenstva prava, demokratiia, prava liudyny - yak osnova ukrainskoho konstytutsiinoho ladu. Pravo Ukrainy. № 5. S. 159-174.

\section{Information about the author:} Boryslavska O., Doctor of Juridical Sciences, Docent, Professor at the Constitutional Law Department, Ivan Franko National University of Lviv ORCID: https://orcid.org/0000-0001-8338-0966 